\title{
KRUSZYŃSKI BARTOSZ
}

\section{COMBAT OPERATIONS OF THE GERMAN 1OTH INFANTRY DIVISION \\ ON THE WESTERN FRONT OF WORLD WAR I IN 1918}

This paper presents combat actions of German 10th Infantry Division of 5th Army Corps in 1918 on the Western Front of World War I - the Second Battle of Marne, battles between the Meuse River and the Moselle River (the battle of the Salient Saint-Mihel) and the operations in the Champagne region and by the Meuse River (Meuse-Argonne Offensive). The analysis of available sources and subject literature has allowed a recreation of 10th Infantry Division's combat route organizational changes which took place during the war, the role of the division in respective battles, and the losses suffered by regiments, including soldiers of Polish nationality which is only partially recorded.

Key words: German 10th Infantry Division; Western Front WWI in 1918; Second Battle of Marne; battles between the Meuse River and the Moselle River; Poles in the German army 1918.

In the spring of 1918, the German General Staff planned to carry out another offensive on the Western Front. The goal was to break through the line of the river Marne and to inflict a decisive defeat on the French troops, before the arrival of the American Division on the Western Front. The decisive blow was supposed to consist of two operations. The first, named "Marne", was to be conducted by the 7th Army under the command of Gen. Hans von Böhn. The second operation received the codename "Reims". Both operations have passed into history as the Second Battle of the Marne (11 June 6 August 1918). For these reasons the aim of this article is to present combat operations of the 10th Infantry Division in the Second Battle of the Marne, Battle of the Silent Saint-Mihel, fighting in the Champagne and along the Meuse River. Apart from the German sources and research, the author used publications by US units, including the 3rd Infantry Division [1], the 1st Infantry Division[2] and books by Michael S. Neiberg[3], Martin Marix Evans[4] and Mark Ethan Grotelueschen[5].

Kruszyński Bartosz, Ph.D, is an assistant professor at the Military History Department, The Faculty of History, The Adam Mickiewicz University in Poznań Poland.

(C) Kruszyński Bartosz, 2018 
In the spring of 1918, with the arrival of the American troops in France, the Allies planned to carry out an offensive by the Marne River. When the German preparations for the offensive in the East and southwest of Reims were detected, the command of the French and the US forces prepared for defensive operations. They decided that they would undertake a counterattack, which would occur after the German offensive. The Germans lost the element of surprise and were to attack their opponent, ready to repel this impact. Moreover, there was only one railway line by the Marne River, which was supposed to provide ammunition for artillery and other material necessary for carrying out the offensive[6, p. 129]. This made it difficult to supply the German army. For the German side, these factors meant their maneuvers were essentially a one-way ticket. It would be not possible to evacuate the valuable war material in the case of the failure of the offensive and the transition of the enemy to a dynamic counterattack[6, p. 129].

Meanwhile, on 11 June 1918, the regiments of the 10th Infantry Division were withdrawn from the front and moved to Sissonne. The soldiers had to rest, and the material and required reinforcements. Kronprinze Wilhelm came to the staging point of the 47th Infantry Regiment on 25 June and decorated soldiers for their actions in the previous battles[7, p. 401]. At the beginning of July, the size of the individual battalions of the Division increased to about 750 soldiers [8, p. 5]. The Division was assigned to the Gruppe "Kathen", which was created on the basis of the XXIII Reserve Corps of the 7th Army. The 36th Infantry Division and the 10th Landwehr Division (which filled the position on the right bank of the river) were also assigned to the Gruppe "Kathen”[9, p. 376]. The 128th Infantry Regiment, the 175th Infantry Regiment and the 5th Grenadier Division of the 36th Infantry Division were designated to storm the eastern flank of the assault. On the western flank of the assault were the 6th Grenadiers Regiment, the 47th Infantry Regiment and the 398th Infantry Regiment of the 10th Infantry Division[4, p. 173; 10, p. 498].

On 7 July, the Division undertook a march towards the front by Eppes, Brenelle and Forêt de Fère to reach the starting position. The Division's line of attack was set next to oxbow of the Marne River, which was winding around the hill to the South from the Meuse River. A strike by the Gruppe "Kathen", which included the 10th Infantry Division, was supposed to take place in the morning on 
15 July 1918. In the meantime, the American 3rd Infantry Division set out for left bank of the river Marne. The units of the 6th Infantry Brigade occupied the following positions: the 38th Infantry Regiment - the line to the town Meuse and the 30th Infantry Regiment - the line from the Meuse (including the town) to Le Rû Chailly Ferme. The 7th Infantry Regiment of the 5th Infantry Brigade occupied the line from Le Rû Chailly Ferme (including) to Blesmes. At the beginning of July, the 7th Infantry Regiment had 2843 soldiers, the 30th Infantry Regiment had 3345, and 3202 for the 38th Infantry Regiment. The positions along the front of the 3rd Infantry Division were organized in several lines. The first line was the zone of checkpoints, which were next to the river, and the resistance points along the railway line. There were two main lines of resistance. The first was the Aqueduct Line, which was drawn north along the ridge of the hill and wound by the river. The second was Woods Line along the Janvier Ferme - le Souvrien Fermé le Rocq Ferme et Château - Fontaine aux Charmes. In support of the individual infantry company, items of the 8th Machine Gun Battalion and the 6th Sapper Battalion of the 3rd Infantry Division were deployed in individual sections of the defense[1, p. 22-23, 98].

The Allied intelligence acquired information about the details of the planned attack of the German troops. The loss of the effect of surprise by the German army obviously did not bode well for them. Specifically, this allowed the French and American artillery fire to concentrate on both areas of German divisions. At 00:15 on 15 July 15, the German artillery began shelling the American 3rd Infantry Division with explosive and fragmentation bullets as well as gas projectiles. The 7th Infantry Regiment suffered heavy losses. The fire of the German guns was intense enough to spark panic amongst the American soldiers, who were not used to the conditions on the Western Front. This phenomenon afflicted, in varying degrees, privates, non-commissioned officers and officers. In one notable case, one of the Commanders of the Regiment of the 3rd Infantry Division had to be evacuated to the homefront[3, p. 10-110; 4, p. 112].

Meanwhile, the pioneers of the 10th Infantry Division, under the fire of the enemy artillery, put up few pontoon bridges. The Posen regiments pushed forward over the Marne River through the pontoon bridges. They crossed the river near the Meuse and Le Rû Chailly Ferme, flanked Fossoy and seized Bois d'Aigremont. At 2:40 am the 
Grenadier Regiment crossed the river on both sides of the Meuse, where it fought against company $\mathrm{G}$ of the 38th Infantry Regiment and company $\mathrm{C}$ of the 30th Infantry Regiment. At 3.30 am the Posen grenadiers mastered the railway line, displacing both enemy companies. However, an effective counterattack of the American company $\mathrm{G}$ and $\mathrm{H}$ of the 38th Infantry Regiment pushed the 6th Grenadiers in the direction of the river. The German infantry managed to infiltrate the American positions of the 3rd Infantry Division to the West of the Meuse. But the company C of the 30th Infantry Regiment, which was supported by two heavy machine guns, resisted[1, p. 25-26].

Further to the West, the German 398th Infantry Regiment crossed the Marne River near the American company B of the 30th Infantry Regiment. Its two battalions attacked first, and the third was to repudiate. During the crossing, the 398th Infantry Regiment suffered significant losses from the artillery fire, but its combat readiness remained high. At 5:00 am the soldiers of the 398th Infantry Regiment took the line of the railway track. However, its wings were exposed and thus vulnerable to counterattack. After 5:00 am, soldiers of the 1st Battalion of the 398th Infantry Regiment began a further attack. However, they were stopped around 9:00 am at the North of Fossoy by two platoons of the company F of the 7th Infantry Regiment. Robert St. James, one of the American soldiers, described this scuffle: ,(...) The Germans pressed on toward them in skirmish formation. The attack never passed beyond this position. Their heroic stand against superior forces can best be told by the number of dead Germans who lay in front of the line, circling the bodies of those two platoons who gave their lives to stem the German advance. It must have been that these men disdained to wait the German's advance but advanced to meet the enemy, for in front of the American line, mingled with German dead, were the bodies of men from these two historic platoons that had died fighting... Of the heroism of individual men of these two platoons too little is known. They halted the Germans and died. One automatic rifleman, Clarence Hensley of Co [Company - BK] J fired his Chauchat until ammunition and crew were gone. A broken Chauchat and the bodies of Germans beside his dead body told the story of his last fight..." [4, p. 112-113].

Included in this attack by the reserve of the 10th Infantry Division was the 47th Infantry Regiment, which had to force the Marne River 
to the West from Meuse. The pioneers began building the bridge in the direction to the West of Mont St. Père Island, next to the position of the American company $C$ of the 30th Infantry Regiment. At 4:00 am when the bridge was completed the soldiers from the I Battalion of the 47th Infantry Regiment went on to the other side of the river. Then, they entered a hurricane of fire from the American company. The battalion took up $200 \mathrm{~m}$ from the southern bank of the Marne River, weighed down with the fire of MGs. Due to the very large losses, survivors retreated on the north shore of the river. Soldiers from the 3rd Battalion of the 47th Infantry Regiment failed to cross by ferry across the river to the West of Meuse. In the course of attempting to force the Marne, they took heavy fire from machine guns and artillery, and thus took shelter in the woods north of Chartèves. The II Battalion of the 47th Infantry Regiment crossed the river successfully, however, upon seeing the defeat of the I Battalion, they stopped and took a defensive position. The further offensive of all three regiments of the 10th Infantry Division did not produce the expected results. American troops resisted by performing hard local counterattacks. At 2:00 am on 15 July the line of defense of the Posen Division was shaped by the railway line on the South Bank of the River - Meuse village and the forest to the North of Crézancy. At 6.30 am the regiments of the 10th Infantry Division received orders to withdraw to the North edge of the Marne River[1, p. 26-31].

During the fighting on the ground, British, French and American aircraft launched intense attacks on the positions of German troops, and heavy bombers made raids on the warehouses by the front. Through first day of fighting only, 45 tons of bombs fell on pontoon bridges. Soldiers of the American 3rd Infantry Division did not have combat experience, and deficiencies in training both at the warehouses, and the regiments were considerable. Despite these problems, the American soldiers turned out to be a hard and relentless opponent[6, p. 130]. The American 3rd Infantry Division was awarded the nickname "The Rock of the Marne" for its attitude in this battle, a name that is still in use today, providing a lasting element of the history of this unit[11].

On 16 July, the second day of fighting, it was already clear that the German plan of forcing to the other bank of the Marne would be impossible to implement. Therefore, the German high command 
issued the order to stop the attack. The regiments of the 10th Infantry Division evacuated from the bridgehead, which was a narrow strip of land located directly on the river[1, p. 26-31]. The American 3rd Infantry Division maintained attacks on the 398th Infantry Regiment, the 6th Grenadier Regiment and the 47th Infantry Regiment of the 10th Infantry Division, but also undertook local counterattacks. The attack ended in a fiasco, and the regiments of the 10th Infantry Division suffered severe losses from fire artillery and machine gun. The 6th Grenadier Regiment reported 173 killed (including 6 officers), 264 gassed (of which many were dead, injured, or missing), 205 injured and 400 taken captive by the Americans (including half of the injured), for a total of 1042 casualties. The losses of the 47th Infantry Regiment on 15-17 July 1918 were significantly smaller and amounted to 60 killed (including 5 officers), 237 wounded (including 10 officers), and 41 missing, resulting in a total loss of 338 soldiers[7, p. 587]. Among the losses of the 10th Infantry Division alongside soldiers of the German nationality were also those of Polish nationality. This is confirmed by the list of losses, which included many Polish surnames. One of them was born in Posen paramedic Vizefeldwebel Stefan Kowalczyk from the 6th Grenadier Regiment. He evacuated many of his wounded colleagues from the heavy fire of artillery to the other bank of the Marne. He was wounded during one of the evacuations [12]. For this action, he received the Iron Cross 1st Class. Although the Iron Cross 2nd Class was widely awarded, the higher class of the award was extremely rare, especially to soldiers of the Polish nationality [10, p. 7-12, 181-183; 13, p. 517, 521].

The American 3rd Infantry Division also ransomed its win with serious losses. On 15-17 July 1918, these totaled 3151 soldiers. In the Posen 10th Infantry Division assault, the losses of the Americans of the 3rd Infantry Division were as follows: the 7th Infantry Regiment 538 injured, 20 dead with wounds and 172 fallen; the 30th Infantry Regiment - 490 wounded, 18 dead with wounds and 151 killed; the 38th Infantry Regiment - 425 wounded, 23 dead with wounds and 184 killed; the 6th Sapper Battalion - 259 wounded, 9 dead with wounds and 39 killed. The 10th Artillery Regiment also suffered big losses from the fire of the 10th Infantry Regiment. The losses amounted to 179 wounded and 23 killed[1, p. 53].

A counter-offensive of Allies launched on 18 July 1918 from the line of the river Marne. The French and American divisions 
pushed of German divisions to the West in a way that was rare so far on the Western Front. The 10th Infantry Division participated in these activities until 25 July[14, p. 104]. Then the regiments of the Posen Division led the retreat fight from 26 July to 6 August to the North of the Marne River, towards the river Vesle[6, p. 181-183; 10 p. 525-531; 13 p. 130-131]. The Division took a defensive position from 4-5 August on the South of the river Vesle[14 p. 104]. Losses incurred by individual regiments of the 10th Infantry Division were overwhelming. In the 47th Infantry Regiment left only 18 officers, 58 non-commissioned officers and 199 privates (combat realm)[7 p. 398].

At the beginning of August 1918, the Posen 10th Infantry Division was moved from the 7th Army to Armee-Abteilung " $\mathrm{C}$ " of the Heeresgruppe "Gallwitz", which was the core of V Army Corps under the command of Lieutenant General Eduard von Below[9 p. 76, 15 p. 392]. The Division's regiments walked from the place of leisure to Athies-sous-Laon, where they were loaded onto the echelons. Then, they were transported on 5 August through Hirson, Charleville and Sedan to the town of Mars-la-Tour. The ranks of the Division composed soldiers from disbanded the 255th Infantry Division (7 August 1918), allowing it to make up losses in personal companies of individual regiments. On the night of 18 to19 August, the 10th Infantry Division returned to the front line, where filled the sector Richecourt-Lahayville-Baussant Saunt (17 km south of Mars-la-Tour) on the left wing of the Silent Saint-Mihiel. It loosened the 277th Infantry Division near the town of Sponvile[10, p. 533-537]. The Division had to take part in the fighting between the rivers Meuse and Moselle, which passed into history as the battle of Silent SaintMihiel (7 August - 20 September 1918).

Due to the fact that Salient Saint-Mihiel had no operational significance, and exhibited the German troops at the unnecessary loss, on 8 September, the Supreme Command issued the order to evacuate to the fortified position of Michel Stellung. For unknown reasons, the divisions that were filling the positions of Salient Saint-Mihiel received the order two days late. Taking into account the fact that not only regiments but also supplies had to be evacuated, the order had to take a few days to enact. As a first artillery began to walk to the new positions. Then the attack of American troops begun and the German infantry was forced to retreat and go to delay action[4, p. 173; 6, p. 134-135]. 
In the forthcoming battles, the 10th Infantry Division had to defend a $13 \mathrm{~km}$ line of the front and deal with the American 1st Infantry Division[16, p. 364]. The 1st Infantry Division had a smaller combat experience, however, they did possess significant advantages in numbers, firepower, and morale. The three regiments of the 10th Infantry Division had to face the 18th Infantry, the 16th Infantry, the 28th Infantry, and the 26th Infantry from the American 1st Infantry Division. Therefore, taking into account the operational disadvantage and the advantage of the enemy, the Posen Division was at an extreme tactical disadvantage, even before the start of the battle. Only the great experience, sacrifice by individual soldiers and good leadership could save the 10th Infantry Division against a breakthrough[5, p. 108-109].

On 12 September, the American IV Corps attacked the 10th Infantry Division. On the left wing of the American Corps was the 1st Infantry Division, in the center, the 42th Infantry Division, and on the right, the 89 Infantry Division. A four-hour artillery onslaught heralded the launch of the attack. Despite the fact that these positions were occupied by the German troops for 4 years, which allowed them to build up a defensive position, regiments of the 10th Infantry Division had no chance to stop so a strong impact. The American intelligence estimated morale and combat potential of the 10th Infantry Division, as high[2, p. 156].

After 19 hours of fierce fighting, the American 1st Infantry Division throw off 10th Infantry Division regiments to $14 \mathrm{~km}$. The front line stopped North of Thiaucourt on strengthened position of Michel Stellung. The initial brunt of the impact was so large that individual units of the 10th Infantry Division suffered significant losses. The 6th Grenadier Regiment lost 1550 soldiers who were dead, wounded or missing on 12 September. One of the captured prisoners was Pater Eustachius Riedel - longtime Roman Catholic chaplain. On 12 September 1918 troops of the 6th Grenadier Regiment suffered losses of 22 officers, 1518 non-commissioned officers and privates. Out of this number 600 soldiers were wounded and 500 were prisoners [10, pp. 559-562]. The losses of the 47th Infantry Regiment amounted to 1415 on 12 September. A large number were missing, and a reference to the American data indicates that most of the missing in action were taken prisoner. Detailed losses of the 47th Infantry Regiment on the day 12 September 1918 are as follow: 2 officers, 11 non-commissioned officers and privates dead, 5 officers, 118 noncommissioned officers and privates wounded, 16 officers, 1262 noncommissioned officers and privates missing[7, p. 416]. 
After the first day of fighting, the American 1st Infantry Division reported much larger losses on the German side. According to these data, the 10th Infantry Division lost around 600 killed and wounded, 1195 taken prisoner (including 5 officers), 30 heavy guns $77 \mathrm{~mm}$ and $150 \mathrm{~mm}, 50$ machine guns, 100 rifles Mauser 98, pistols, revolvers and stocks of ammunition, as well as 3 locomotives (narrow-gauge). While the loss of the 1st Infantry Division amounted to 84 people killed (including 2 officers), 489 injured (including 11 officers) and 19 missing. Germans captured one American captive [7, pp. 404410; 17]. After the battle of Salient Saint-Mihiel in the Pannes (West of Saint-Mihiel), within the 47th Infantry Regiment, only three infantry companies remained, with three machine guns, and a mortar company[18, p. 98].

The III Battalion of the 398th Infantry Regiment was entirely taken prisoner by the American troops on the first day of fighting. An un-named Colonel from the 10th Infantry Division was taken as captive by the American 1st Infantry Division. The Colonel was impressed with the attack carried out by American troops, which was quickly communicated by a staff of the 1st Infantry Division, together with the statement of the officer. The German Colonel particularly well appraised the firepower and accuracy of the American artillery, whose fire effectively paralyzed any maneuvers of regiments of the 10th Infantry Division[2, pp. 360-361].

Capt. Weis, a German intelligence officer, was less optimistic about the attitude of the American troops. He said that the American infantry soldier was poorly trained, could not deal with the obstacles encountered during the attack and the advantage of the terrain. In his opinion American officers did not have leadership qualities. However, he emphasized the excellent use of American machine gun infantry and the effectiveness of their artillery[4, p. 173-174].

This battle did not constitute a significant defeat for the German side, and as such was not a great success for the American side as well. However, it was presented as a great victory in the Chronicles of the troops of the 1st Infantry Division. Undoubtedly, the battle was further proof how large the Allied advantage had already become. At the same time, these events predicted the upcoming defeat of German troops on the Western Front[5, p. 108]. 
From 15-20 September, the 10th Infantry Division led the defensive position under the Woëvre-Ebene West of the river Moselle[14. p. 104]. After 21 September, the 10th Infantry Division was moved from Armee-Abteilung "C" of the Heeresgruppe "Galwitz" to the 19th Army of Heeresgruppe „Herzog Albrecht”[15, p. 80]. From 20 September to 13 October 1918 the regiments of the 10th Infantry Division suffered further heavy losses in the fighting position in Lorraine, which led to the loss of combat capability of this unit. At the end of September, the rifle companies of the 6th Grenadier Regiment shrunk to 60 soldiers and $4 \mathrm{MG}-08 / 15$ machine guns. In the entire regiment, only 82 officers and aspirants remained, along with, 1875 non-commissioned officers and grenadiers and fusiliers, 28 horses, 18 heavy machine guns (type MG-08) and 55 light machine guns [10, p. 563-564].

In order to restore their combat capacity, the 10th Infantry Division was transported to the Bezirk Lothringen - the German administrative area with the capital in Metz. The Division was supplemented by soldiers from the disbanded the 77th Reserve Infantry Division. In this way, the soldiers of disbanded the 275th Reserve Infantry Regiment replenished the 6th Grenadier Regiment, and the soldiers from the 419th Reserve Infantry Regiment replenished the 398th Infantry Regiment. All three infantry battalions were rebuilt in the 332th Reserve Infantry Regiment, while the mortar company from the 47th Infantry Regiment was also rebuilt[13, p. 181-183]. Further deliveries of materials and additions came from Germany. On 30 September, the last supplement for the 47th Infantry Regiment came from the Warthelager near the city of Posen (Polish: Poznań) during this war. The supplement contained 2 non-commissioned officers and 35 privates[7, p. 595]. These additions helped to increase combat state of the 6th Grenadier Regiment to 82 officers, 1875 noncommissioned officers and grenadiers (Filizerów)[10, p. 564] at the end of September. The 56th Field Artillery Regiment included 24 officers, 260 non-commissioned officers and privates and 104 horses[19, p. 166]. This allowed to the 10th Infantry Division to return to the fight. On 5 October 1918 its regiments passed to the sector in the vicinity of the village of Nomeny, $17 \mathrm{~km}$ east of the Moselle River and the town of Pont-à-Mousson, where they remained until 28 October. In the meantime, there have been organizational 
changes. The 10th Infantry Division was moved from the 19th Army of the Heeresgruppe "Herzog Albrecht" to Armee-Abteilung " $C$ " of the Heeresgruppe "Galwitz" on 11 October[5, p. 82; 15, p. 129].

The last clash on the Western Front of World War I in which the Posen 10th Infantry Division participated, was an attempt to stop American troops during the Meuse-Argonne Offensive in the Champagne region and along the Meuse River in Lorraine (3 October11 November 1918). The American Expeditionary Forces Headquarters (AEF) designated nine divisions to attack, which were supported by 2,700 guns, 189 tanks and 821 planes. The American strike was intended to break the third line on the German position to a depth of $16 \mathrm{~km}$ in the two-day offensive. This third line of German positions was named the Stellung "Kriemhild" and was part of the Hindenburg Line. Meanwhile, the Posen 10th Infantry Division was moved from Armee-Abteilung " $C$ " to the 3rd Army, and then to the Gruppe Soden (command of the $\mathrm{V}$ Army Corps) from the 5th Army[9, p. 83; 15, p. 398]. After marching to the town of Metz, the Division was transported by the rail through Longuyon to Montmédy. On 2 November, the Division took a position on the Northwest of Stenay (between the rivers Aisne and Meuse). Intense fighting with the American troops that were invading between the river Meuse and Beaumont constantly continued from 4 to 11 November 1918. On the last day of the fighting, the 10th Infantry Division took captives from the American 5th Infantry Regiment. The 56th Infantry Regiment fired on enemy positions 7,000 bullets[19, p. 171].

At 10:00 am on 11 November 1918, the 10th Infantry Division, which was on positions on the line of the Meuse River, received notice of the ceasefire. This meant an end to the long-lasting and debilitating fights. In accordance with the agreement, the German troops were to withdraw from France, Alsace and Lorraine and the left bank of the Rhine River during the next 15 days[6, p. 141]. On 14 November, the 10th Infantry Division took march in a westerly direction through Luxembourg. On 21 November, the division reached Senningen. On 2 December, the 10th Infantry Division was in Mainz on the river Rhine, where a day later went to an area of the city of Homburg. Due to a low number of soldiers, the I and II battalion of the 6th Grenadier Regiment were combined in the Battalion "Reimer". The name "Reimer" came from the surname of its commander Capt. Reimer. 
The 1 st and the 2 nd company of machine guns were also combined. The 3rd company of machine guns was withdrawn from the regiment. The Battalion "Reimer" (on 22 December) and the Battalion of Fusiliers (on 24 of December) from the 6th Grenadier Regiment went from Gelnhausen to their native garrison in Posen[10, pp. 563-564; 577-585]. On December 28, the staff, I and III battalion of the 47th Infantry Regiment left Büdingen by train. They arrived at Schrimm garrison (Polish: Śrem) in the Provinz Posen on 30 December. However, due to the outbreak of the Greater Poland Uprising, the city at that point was under the control of the native Polish insurgents, thus the regiment was directed to the Glogau (Polish: Głogów) in Legnica [7, p. 434].

The Posen 10th Infantry Division was composed of „Kaczmarek\&apos;s Regiments” and was assessed as an effective in battle by opponents. The largest part of the soldiers was peasants, craftsmen and inhabitants of the towns of the Province of Posen. Polish nationality reservists who were conscripted into the ranks of the German troops, in most cases, behaved loyally[13, pp. 181-183]. One of the soldiers of the 6th Grenadier Regiment wrote about the value of the Division:

"Kaczmarek Regiments, with smaller and high numbers, melted in the mud, fire and blood. The Posen divisions, shunted from place to place, have not lost in the marches and battles their values of discipline, and remain hard and extremely stubborn soldiers. The Posen "peasants from the villages" were the physically and morally healthiest soldiers because they were raised in the iron obedience of the Prussian schools and trained by Prussian officers and noncommissioned officers. They were physically and mentally strong. Physically - as compared with the population of big cities and industrial districts, because they always provided the largest number of healthy and strong conscripts recruits. Morally, because in the country, mostly without the proletariat, working-class social democratic parties did not have the environment and the ground to establish and develop wider policies"[20, pp. 20-21].

Despite this, the German staff feared that the Polish element of this Division would affect its prowess, or would be a source of desertions. The staff tried to counteract this and undertook several actions to reduce Polish element in the Division from December 1916, prior to 
deployment into Verdun. For instance, the Posen 47th Infantry Regiment received the supplement from the IX and X Army Corps, instead of the V Army Corps, and the 9th and the 10th Infantry Divisions received companies from the 103th Infantry Division from Hesse and Thuringia. A further supplement of recruits came from the Province of Posen. Therefore, it was impossible to avoid the Polish soldier\&apos;s element, which fought with a lot of dedication in contrary to the concerns of German command. Although there were desertions of Polish soldiers in Prussian regiments, the practice never took place on a large scale[13, pp. 181-183].

The Polish inhabitants of Posen and the Province of Posen had to wear German uniforms and fight for foreign powers during World War I. Many of them never returned to the home, and their families today are not familiar with the burial place of their loved ones. According to estimates during World War I, the German army incorporated 850 thousand soldiers who spoke Polish, which represented $6 \%$ of all mobilized in the German Empire. Over 130,000 out of 850,000 fell or were missing or died from the disease in the course of combat actions on all fronts of the war. To mid-December 1914 all soldiers above 30 years of age that were mobilized in August 1914 in the Posen V Army were wounded at least once[21, pp. 1138-1139, 1147].

The participation of the inhabitants of the Province of Posen in the ranks of the German army during World War I passed into oblivion after 1918. This occurred, because on the one hand, these facts of Kaiser Wilhem's army veterans were not a point of pride for the inhabitants of Posen. While, on the other hand, the memory of the Greater Poland Uprising of 1918/19 and the Polish-Soviet War 1919-20 had much more important national significance, particularly in light of the long-awaited return of Polish independence. Medals, among them the Iron Cross 2nd Class, and photographs from the Great War reminded. They lied hidden in a metal box in the kitchen closet for many of the veterans and their families. Only rarely would a veteran of World War I, such as Jan Kroll [22, p. 91] (born in 1898 in Lusówko near Posen - great-grandfather of the author of this text) from the 56th Field Artillery Regiment of the 10th Infantry Division, tell war stories about the battles of Verdun[23]. His younger brother Andrzej - a soldier of the 230th Reserve Infantry Regiment from the 
50th Reserve Division, never returned from the war to the family home. He died at the age of 20 on 14 March 1916 on the Western Front at Vimy (North of Arras). His grave has never been found, mirroring the fate of many of these Polish soldiers.

The soldiers from regiments of the 10th Infantry Division showed courage and bravery during extremely bloody battles on the Western Front, which is confirmed by numerous awards they received. One hundred forty-two soldiers from the 56th Infantry Regiment received the Iron Cross 1st Class and 2020 soldiers earned the Iron Cross 2nd Class. Of these 2020, 4 officers also earned commendation Den Hausorden der Hohenzollern mit Schwertern[19, pp. 210-203].

Preliminary calculations show that over 100,000-150,000 soldiers of the Polish nationality went through the V Army Corps in the years 1914-18. The losses of the 47th Infantry Regiment included numerous Polish surnames written in the German style. For instance there was musketeer (Muskieter) Leo Pawlowski from the 4th company of the II reserve battalion, who was lost on 4 March 1915, musketeer Karl Muszejewski of the 10th company, who was lost on 25 March 1915, Anton Nawrocki from the 6th company, who was lost on 22 September 1914, and Stanislaus Adamiak from the 8th company, who died on 17 July 1915[7, pp. 534-577]. The similar situation was in other units of the $\mathrm{V}$ Army Corps. These data, however, are only an estimate. The identification of the specific numbers, and names requires further research, especially in the family archives.

1. 3rd Division. Summary of Operations in the World War / Washington, DC: American Battle Monuments Commision, 1944.

2. History of the First Division during the World War 1917-1919/ Philadelphia : The Society of the First Division, 1922.

3. Neiberg M. S. The Second Battle of the Marne / M. S. Neiberg. — Bloomington: Indiana University Press, 2008.

4. Evans M. M. 1918 the Year of Victories / M. M. Evans. London : Arcturus Publishing Limited, 2002.

5. Grotelueschen M. E. The AEF Way of War. The American Army and Combat in World War I / M. E. Grotelueschen. Cambridge : Cambridge University Press, 2007.

6. Volkmann E. O. Wielka wojna 1914-1918 / E. O. Volkmann. - Oświęcim : Wydawnictwo Napoleon V, 2013. 
7. Loosch G. Das Königl. preuss. Infanterie-Regiment König Ludwig III. von Bayern (2. niederschl.) $\mathrm{nr} 47 \mathrm{im}$ Weltkrieg 1914-1918 und im Grenzschutz 1919 nach d. amtl. Kriegstagebüchern u. berichten von Mitkämpfern / G. Loosch. Zeulenroda : Sporn, 1932.

8. Bauer G. Handbuch der verbände und Truppen des deutschen Heeres 1914 bis 1918 Teil VI: Infanterie, Band 1: Infanterie-Regimenter / G. Bauer, J. Kraus. - Wien : 2007.

9. Die Schlachten und Gefechte des Grossen Krieges 1914-1918 / Berlin : H. Sack, 1919.

10. Gottberg F. D. von Das Grenadier-Regiment Graf Kleist von Nollendorf (1. Westpreusisches) nr. 6 im Weltkriege / F. D. von Gottberg. - Berlin : Bernard \& Graefe, 1935.

11. US Army, Fort Stewart Garrison (USA), "3rd Infantry Division History", <http://www.stewart.army.mil/>, [accessed february 20, 2015]/ .

12. Armee-Verordnungsblatt. Verlustliste 1918, Ausgabe 2105,26300 .

13. United States Army. American Expeditionary Forces. General Staff G.-2 Histories of Two Hundred and Fifty-One Divisions of the German Army which Participated in the War (1914-1918) / G.-2 United States. Army. American Expeditionary Forces. General Staff. - Washington D.C. : Washington G.P.O., 1920.

14. Lezius M. Ruhmeshalle unserer alten Armee / M. Lezius. Leipzig : Militär-Verlag, 1927.

15. Der Weltkrieges 1914 bis 1915 / Berlin : Verlag Ernst Siegfried Mittler \& Sohn, 1944.

16. Gallwitz M. von Erleben im Westen 1916-1918/ M. von Gallwitz. - Berlin : Verlag Mittler \& Sohn, 1932.

17. Thillot-sous-les-Côtes, Lorraine, France, Département de Meurthe-et-Moselle, Lorraine, France World War I papers. military collection. State Archives of North Carolina, milcoll.wwi.maps.

18. Kraus J. Handbuch der verbände und truppen des deutschen heeres 1914-1918, Teil VI: Infanterie, Band 1: Infanterie-Regimenter / J. Kraus. - Wien : Verlag Militaria, 2007.

19. Angerstein K. Das 2. posensche Feldartillerie-Regiment nr. 56 (1914 bis 1918) / K. Angerstein, P. Schlemm. - Berlin: 1927.

20. Prauziński L. W marszu i w bitwie. szlakiem powstańców wielkopolskich 1914-1920 / L. Prauziński, A. Ulrich. - Poznań : Księgarnia Św. Wojciecha, 1939. 
21. Watson A. Fighting for Another Fatherland: The Polish Minority in the German Army, 1914-1918, "English historical review" / A. Watson // - Vol. Vol. CXXVI, 522/2010. - P. 1138-1139.

22. Kruszyński B. Biogram Jana Krolla / B. Kruszyński. Poznań : 2008. - 91 p.

23. The Interviews with Jan Kroll were conducted on 7 july 1994 in Grodzisk Wielkopolski [the record in the author's archive].

Надійшла до редкеолегії 18.08.2018 р.

\section{Крушиньський Б. \\ БОЙОВІ ДІЇ 10-Ї ПІХОТНОЇ ДИВІЗІЇ НІМЕЧЧИНИ НА ЗАХІДНОМУ ФРОНТІ ПІД ЧАС ПЕРШОЇ СВІТОВОЇ ВІЙНИ У 1918 РОЦІ}

У цій статті розглянуто бойові дії 10-ї піхотної дивізії 5-го армійського корпусу Німеччини на західному фронті під час Першої світової війни в 1918 році, що розгортались під час Другої битви на Марні, битві між річками Мейс і Мозель (Сен-Мієльська операція) та операцій в регіоні Шампань і річки Мейс (Мез-Аргоннська операція). Аналіз доступних джерел та предметної літератури дозволив відтворити організаційні зміни в маршруті 10-ї піхотної дивізії, які відбулися під час війни, описати роль дивізії у бойових діях та переглянути втрати, яких зазнали полки, де служили бійці польської національності, про яких відомо лише частково.

Ключові слова: 10-та піхотна дивізія Німеччини; західний фронт під час Першої світової війни в 1918 року; Друга битва на Марні; битви між річками Мейс і Мозель; поляки в німецькій армії в 1918 році. 